\title{
TESTING THE NEW URBANISM PRINCIPLE OF SUSTAINABLE TRANSPORT IN THE CONTEMPORARY REDEVELOPMENT PROJECTS. LESSONS FROM CLICHY-BATIGNOLLES IN PARIS AND THE STATION AREA IN LODZ
}

\author{
Monika Maria CYSEK-PAWLAK \\ Lodz University of Technology, Lodz, Poland
}

\begin{abstract}
As accessibility becomes a basic need of modern society, the issue of sustainable transportation continues to gain importance. On the large scale, it concerns interconnecting cities and metropolises, and, on a smaller scale, it refers to connection networks for pedestrians, cyclists and other means of public transport. The study aims to assess the importance of sustainable transport as a principle of New Urbanism in contemporary redevelopment projects. It introduces possible ways of implementing these principles, as well as dangers coming from misunderstanding them. The approaches and methods used in this article combine field studies conducted during the research trips desk research and interviews with professionals at various stages of two urban renewal projects - Clichy Batignolles (France) and the main train station area in Lodz (Poland). The study revealed the strategic role of rail line redevelopment projects in both rebuilding the continuity of the urban fabric (Clichy Batignolles) and in creating a new centrality for an area with attractive cultural activities and services (Lodz). As urban project timeframes are often long, both case studies show that high flexibility and the ability to adapt investments to changing conditions are often required. Nevertheless, the realization of the key infrastructure elements should be maintained all along. Furthermore, functional diversity can provide an important support for the sustainability of the project as it ensures the quality of urban tissue through height level representative public projects, thereby giving the area in question a new image. As exemplified by the housing policy in France, the distribution of functions can also serve as a pertinent response to the strategic needs of the entire agglomeration as well as a useful solution to local problems. One of the most crucial elements of redevelopment projects is the implementation of sustainable transportation that provides quick and comfortable connections by various means of public transport within different urban scales: metropolises, cities, districts and the city. As an element of sustainable urban policy, an effective public transportation network in the inner city should be supported by the limitation of car park ratio for non-residents within the redevelopment project. Altogether, the impact that other New Urbanism principles exert on developing urban structures is a pertinent question. Today, the real challenge for this movement has moved into the city, rather than on the outskirts, as in the past.
\end{abstract}

Key Words: new urbanism, sustainability, Clichy Batignolles, Lodz.

\section{Introduction}

The immediate association of the New Urbanism movement is the idea of pedestrian-oriented urban patterns. This development design is adapted for human-scale endeavors, with the aim of restoring city centers by reconfiguring sprawling suburbs (Talen 2013). To that end, a range of environmentally-friendly transit alternatives referred to as 'sustainable transportation' in the title. Both international organizations (European Communities Commission 1993, World Bank 1996, WBCSD 2004, International Energy Agency 2009, European Commission 2011) and individual researchers have coined similar definitions of mobility. This article assumes that sustainable transportation refers to efficient solutions in the context of environmental, social, economic, and spatial aspects. 
In order to create a green mobility system, broader planning projects that include various aspects of sustainable development are necessary. The Congress for the New Urbanism (2000) suggests that a number of guidelines defined in their charter of principles be applied to modern urban developments, which are currently largely monopolized by cars. As Calthorpe (2000: 68) stressed, "the real goal, of course, is improving people's mobility and access, not just reducing auto congestion. And this depends more on promoting different land-use patterns than building new roads". Even simple decisions such as locating everyday destinations closer to the workplace or home can be perceived as an effective strategy. The proponents of New Urbanism stress that public spaces (including roads) are too important for the community to be taken up by cars, and they should instead serve more to human needs (Schuyler 1997: 346). The debates of such forerunners as Krier (2009), and Calthorpe $(1993,2000)$ should also be mentioned here. Their arguments bear upon the work of Kunstler (1993), Farr (2008), Talen (2008), Speck (2012), and Langdon (2017). There are also studies that have found positive correlations between travel mode and spatial design elements such as mixed uses programming or density (Frank and Pivo 1994, Cervero 1996, Cervero and Radisch 1996, Cervero and Kockelman 1997, Moudon et al. 1997, Crane and Crepeau 1998, Boarnet and Crane 2001, Greenwald and Boarnet 2002, Saelens et al. 2003, Rodríguez et al. 2007).

An analysis of sustainable transportation, perceived as one of the principles of New Urbanism, cannot overlook the notion of transit-oriented development (TOD). This approach is considered to be a model that prevents auto-dominated landscapes (Ellis 2002, Lin and Gau 2006). TOD is associated with high density design around hub stations (Ma et al. 2018). Calthorpe (1993: 56) defined TOD as: "a mixed-use community within an average 2000-foot [approximately $600 \mathrm{~m}$ ] walking distance of a transit stop and core commercial area. TODs mix residential, retail, office, open space, and public uses in a walkable environment, making it convenient for residents and employees to travel by transit, bicycle, foot, or car." Transit-oriented development has also attracted attention in the scientific literature (Cervero and Sullivan 2011, Dorsey and Mulder 2013, Papa and Bertolini 2015, Qviström and Bengtsson 2015).

Based on the literature quoted above, this article presents original conclusions about the influence of sustainable transportation as an element of the comprehensive New Urbanism approach to the renewal of degraded post-industrial areas. The presented research aims to assess the significance of green mobility in contemporary redevelopment projects in the context of other elements that, according to the CNU definition, define the space. The article sets out possible methods of implementing sustainable transportation and highlights the potential threats that a mistaken interpretation may lead to (an excess of road infrastructure over public spaces designed for pedestrians).

\section{Methodology}

The article is part of a larger research project developed by the author devoted to the principles of New Urbanism. The study aims to present a comprehensive assessment of the impact that the key principles of the movement have on the redevelopment of post-industrial areas today. The methodology discussed below has therefore been complemented by a broader study of New Urbanism itself. Elements of literature review relevant to sustainable transportation have been presented in the introduction.

The methodology used in the article comprises case studies allowing, as Tellis (1997) underlines, to gather together different types of data, and enabling the understanding of the local context. Moreover, the comparative approach adds to the method more universality (Faure 1994). Finally, the comparative methodology of including international cases (Nadin 2012), places the observations in a national context, thereby helping to define guidelines for state-wide policy. 
Testing the New Urbanism Principle of Sustainable Transport in the Contemporary Redevelopment Projects. Lessons from Clichy - Batignolles in Paris and the Station Area of Lodz

The study involved four stages, which took place in various locations over the last few years. During the first stage, the research method and criticism used were based on Polish and French literature connected to the subject. Working materials and project documents were obtained from the participants of the analyzed projects. The desk research also referred to statistical data obtained from the Central Statistical Office in Poland (GUS) as well as the National Institute of Statistics and Economic Studies in France (INSEE). Analysis of strategic planning documents such as those related to the operational urbanism and city council resolutions, allowed to reveal the execution of urban policy within the examined areas. These analyses were followed by observations which allowed to define the walkability of the analyzed zone, its limits, and connectivity with the surrounding urban fabric and the heart of the city (comfort, directness and time framework). The analysis was performed during a research stay at the Institute for Town and Regional Planning at the University Paris-Sorbonne in September 2017 , and in Lodz, during the work at the University of Technology. The aim of this stage was to verify the data gathered in the first part of the research project in situ, and to make an empirical assessment of the transformation in the area. The GIS was based on the Urban Atlas data, and, next, the Autodesk AutoCAD software was used. At the third stage, the data gathered underwent a comparative analysis. The basic elements of comparison were:

- the location of the project within the entire urban tissue;

- the timeframe of implementing the objectives;

- the understanding of sustainable transportation in urban policy;

- the scale of the investments (how the need for accessibility between the site and other elements of the city center, and between the site and housing areas on the outskirts of the agglomeration should be taken into consideration);

- the proposed modality transport and its capacity (which mode of transport the project gives priority to, what the consequences of this decision are);

- the parking policy implemented within the site, in the context of the strategy adopted for the urban area;

- the ratio of roadways to the total area of the site.

Research approaches included quantitative as well as qualitative studies depending on the examined issue. The results were presented in tables defining the main urban indicators, as well as the representativeness of studied cases. The above analysis was used to compare the Clichy-Batignolles area in Paris with the redevelopment project of the station district in Lodz. Both projects are at different stages of completion. On the one hand, this allows us to clearly see the dynamics of implemented changes and include our conclusions in our own project to improve it. On the other hand, it introduces a certain level of complexity. This aspect was taken into consideration during the fourth and final stage of the study: formulating conclusions in the context of possible research and practical perspectives. The chosen case studies were selected to illustrate current tendencies in Western and Central Europe. The comparative study allows, therefore, to define some general rules for this part of Europe. These guidelines are all the more valuable because many European urban systems, especially those from Eastern and Central Europe, use French examples, and they adopt them to their own needs, as it can be observed in former Polish strategies (Skalski 2009). Some of identified tendencies could be perceived as urban Europeanization (Coudroy de Lille 2016).

\section{Results}

Strategic position on the rail line as a basis for reevaluating the degraded zone

The site of Clichy-Batignolles (Fig. 1) is located in the northwest part of Paris, in the 17th arrondissement; it spans 133 acres (54 ha). This new development around Martin Luther King Park aims to connect neighborhoods that were historically separated by the railway network. 


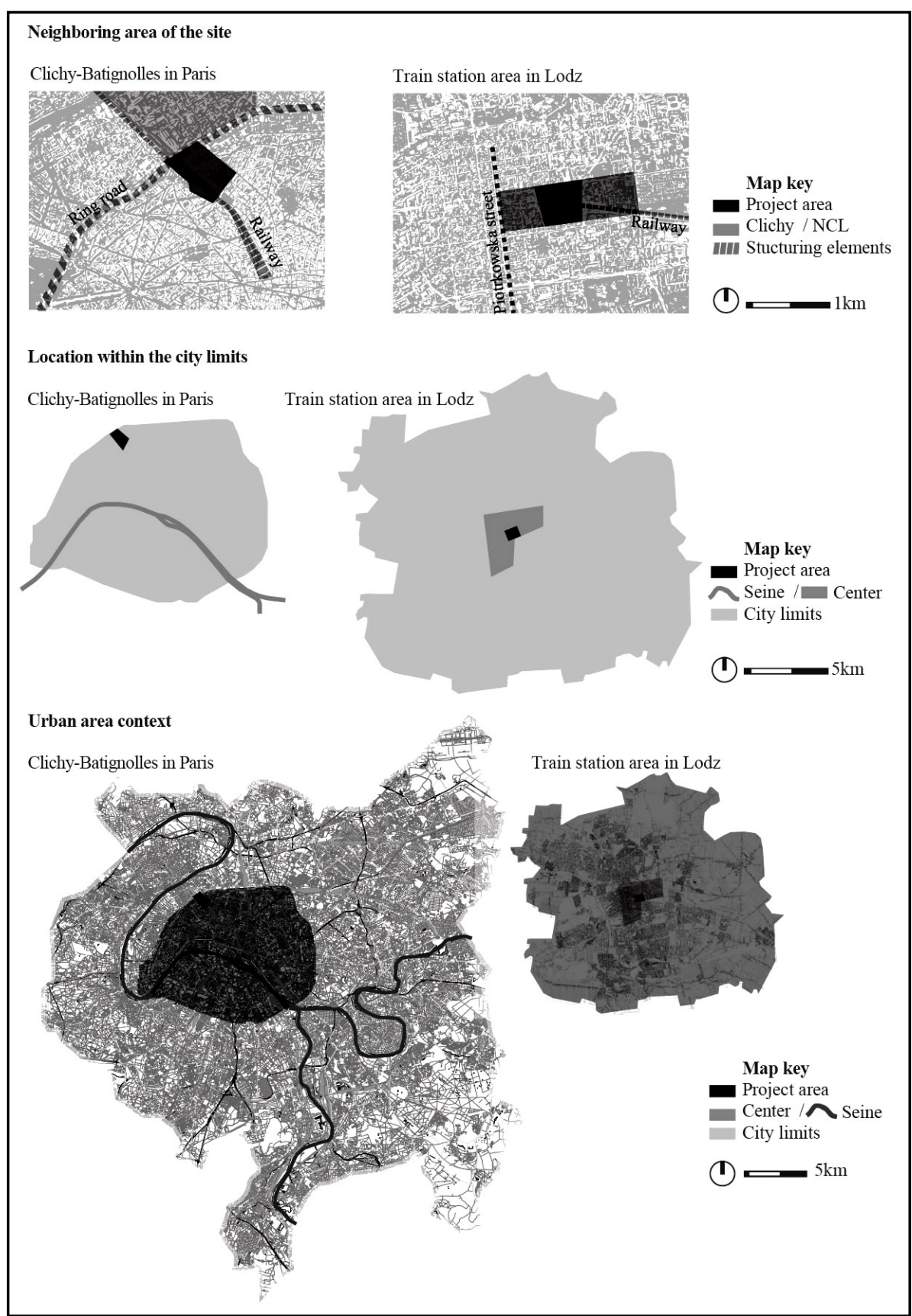

Fig. 1- Neighboring area of the site

Source: developed by the author based on the strategic planning documents of Paris and Lodz 
Testing the New Urbanism Principle of Sustainable Transport in the Contemporary Redevelopment Projects. Lessons from Clichy - Batignolles in Paris and the Station Area of Lodz

The project was conceived as a sort of bridge between the more bourgeois zone in the west (the historical core of Paris) and the working-class area in the north (the suburban commune of Clichy). It rebuilds the continuity of urban fabric in a zone that has traditionally been devoted to logistics: mainly heavy transportation. Apart from the tracks of Saint-Lazare, the Paris ring road also poses a barrier: the Boulevard Peripherique. The Batignolles site includes a marshalling yard located on Petite Ceinture ${ }^{1)}$. After the redevelopment of the rail infrastructure, the PontCardinet station was preserved, served by the Transilien Line $L$ trains (Paris-Saint-Lazare network), and the technical tracks were reduced to the minimum. The industrial heritage of the site is not only limited to the railway, but also to buildings such as the opera warehouse or the power plant.

The area in Lodz, spanning 94 acres (38 ha), also includes several post-industrial buildings The emblematic elements include: a heat and power plant (EC1) that has recently been turned into an open Science and Technology Museum, a conference-and-arts center, and a planetarium. As with Clichy-Batignolles, the analyzed area was released from the infrastructure zone. In Lodz, the alliance between the city and the rail took the form of a modern multimodal station, which was partially moved underground. The Lodz Fabryczna train station has always been the most important element of the circular railway line ${ }^{2)}$, as its most central terminus. The area in the immediate vicinity of the train station in the historical center was recognized by the city authorities as an area of strategic redevelopment in the New Center of Lodz (NCL) within the regeneration project (Table 1). The NCL is divided into three sections that differ in terms of building types. The renewal of the historical city block was planned in the area closest to the historical city center, i.e. to ul. Piotrkowska. The elements related to transportation and culture will dominate around the station. To the east, the layout will be closed by a housing and commercial program. The presented study focuses on the central zone.

Location indicator

Table 1

\begin{tabular}{|c|c|c|c|}
\hline \multirow{3}{*}{ Indicator } & Variable & $\begin{array}{c}\text { Clichy- } \\
\text { Batignolles }\end{array}$ & $\begin{array}{c}\text { Train station } \\
\text { area } \\
\text { in Lodz }\end{array}$ \\
\hline \multirow{4}{*}{ Location } & Brownfield site & $\bullet$ & $\bullet$ \\
\cline { 2 - 4 } & $\begin{array}{c}\text { Heart of agglomeration } \\
\text { whose character was changed }\end{array}$ & $\bullet$ & $\bullet$ \\
\cline { 2 - 4 } & $\begin{array}{c}\text { Old spatial barriers removed in order } \\
\text { to rebuild historically separated } \\
\text { neighborhoods }\end{array}$ & $\bullet$ & \\
\hline
\end{tabular}

The complexity of the urban project timeframe: changes of ideas, conditions, and actors

The transformation of the station district in Lodz started out when the city, five years after closing down the power plant, bought back the EC1 buildings (2005). The initial contracts between the municipal authorities and the Polish Railway Group (PKP) were signed a year later. Rob Krier, a town planner known for a fondness for classical aesthetics, began

1) Initially, Petite Ceinture was only a freight line, and it later gradually started accepting passengers.

2) The circular railway line surrounds the historical core of Lodz, in a way similar to Petite Ceinture, and it serviced both passengers and cargo. 
developing a plan to manage the area. The entire project was solidified when the Minister of Infrastructure announced that in five years' time, the construction of the Polish high-speed rail would start, and that it would go through Lodz (2008). After consultations with the engineers, decision-makers at the ministerial level decided that a comprehensive redevelopment of the Lodz Fabryczna station, which would include a cross-city tunnel underground, was needed ${ }^{3}$. The situation became more complicated when, after the minister was replaced, the high-speed rail idea was abandoned. Later, the authorities decided to revoke the cancellation, and to postpone the project instead. The cancellation of the rail project, however, did not hamper the redevelopment of the station zone in Lodz, and the station was closed down that year. In the meantime, work continued on the master zoning plan (MPZP) in the station district. The plan needs to be adapted in order to accept and include some of the project decisions made while drawing up the train station project (Resolution No. III/40/14 \& III/41/14 of the City Council in Lodz 2014). On the assumption that the area under development would become a live revitalization lab, Poland registered the Lodz's application to hold the International Specialized EXPO 2022 precisely in this area. The proposed topic was: City Re-Invented (2015). However, Buenos Aires' victory meant that Lodz's chance for promotion, and the development that such a major event would facilitate, was lost (2017). In the meantime, the new Lodz Fabryczna train station was opened and a plot in the area, the most expensive one in the history of Lodz, was sold to a private investor (2016). Gradually, EC1 buildings are being opened up having been adapted to their new functions. Work on building a cross-city tunnel continues, but only concerning a conventional rail project. The end of the renovation is planned for 2022. If the Polish high-speed rail is to be finished around 2028/30, then another tunnel under the city will have to be built before then. In short, the whole project of developing the station area has already been underway for 13 years. The key elements of the project should be finished within 25 years.

The timeframe of Clichy-Batignolles is similar to that of Lodz (Table 2), as, according to the timetable, its strategic elements will take 20 years to come to fruition - and given that it is now in its 18th year of implementation. After the official announcement by the Council of Paris that an exemplary eco-district (2002) would be created, an attempt was made to host a strategic mass event in the investment area, in that case - the Olympic Games in 2012. It was also then that the city began buying back plots from the French railway company (SNCF). A year later, designers started their work under the aegis of an architect and urban planner, François Grether, and a landscaper, Jacqueline Osty (2004). The decision to choose London to host the Olympic Games meant that the plans for the Olympic Village needed to be altered. The project team and the ideas behind the development around the central park remained the same (2005). The Prime Minister sequentially approved moving the railway activity to the north (2006) and opening the first part of Martin Luther King Park (2007). Finally, it was announced by the national government and the municipal authorities that the building of the High Court (Tribunal de Grande Instance) would form part of the project (2009). It is worth stressing that an operational plan for Clichy-Batignolles (ZAC) was designed at the same time. At the beginning of the next decade, there was some significant construction work going on: the regional rail system (RER) was covered and the first apartment block in the area was completed (2012). Today, almost all of the eastern part of the buildings are already operational, and the remaining buildings, including the key infrastructure, are to be finished gradually by 2020 (T3 tram, extension of the $14^{\text {th }}$ metro line).

\section{In search of sustainability in the urban functional plan}

One feature of the Clichy-Batignolles project is the importance of the area around the central Martin-Luther-King Park, whose target area should reach 25 acres (10 ha), and half has

3) The Lodz Fabryczna station has traditionally been a terminal station, so the trains need to go in and reverse out again in order to proceed, which obviously takes more time. 
Testing the New Urbanism Principle of Sustainable Transport in the Contemporary Redevelopment Projects. Lessons from Clichy - Batignolles in Paris and the Station Area of Lodz

Timeframe indicator

Table 2

\begin{tabular}{|c|c|c|c|}
\hline \multirow{2}{*}{ Indicator } & Variable & Clichy-Batignolles & $\begin{array}{c}\text { Train } \\
\text { station area } \\
\text { in Lodz }\end{array}$ \\
\hline \multirow{4}{*}{ Timeframe } & $\begin{array}{c}\text { Completion of the initial project idea } \\
\text { for the project }\end{array}$ & - & - \\
\cline { 2 - 4 } & $\begin{array}{c}\text { Realization of key infrastructure } \\
\text { elements }\end{array}$ & in progress & in progress \\
\cline { 2 - 4 } & $\begin{array}{c}\text { Time from the project initiation to the } \\
\text { present day }\end{array}$ & 18 years & 13 years \\
\cline { 2 - 4 } & Total estimated duration of the project & 20 years & 25 years \\
\hline
\end{tabular}

already been opened. It constitutes $18.5 \%$ of the whole area of the development. This park, with its various leisure activities, will be the largest one in northwestern Paris. Another element that is characteristic of the Clichy-Batignolles site is the role of public buildings in the project: $31.5 \%$ of the total floor area. The flagship investment is the courthouse designed by Renzo Piano. In addition to the typical Res Publica, there are also many urban services in the area (a recycling center, bus and coach parking and a concrete plant). All these elements are concentrated close to the ring road and railroad tracks, so as to reduce their nuisance. A dominant component of the built-up area is housing, whose percentage is slightly above that of public buildings in the area: $34.5 \%$. In accordance with national and local laws in France, a variety of sizes, standards and typology of apartments was guaranteed in the project (as reported by the investor, Clichy-Batignolles will ultimately offer $50 \%$ social housing, $20 \%$ capped-rent housing and $30 \%$ housing at market prices). As well as regular apartments, there are housing units for university students and young working people, and rooms for dependent seniors being offered. While analyzing the issue of sustainable transportation in the projects, the share of roadways in the site, where the impermeable surface makes up to only $12 \%$ of the total development area, is worth stressing (while total roadways make up to $16 \%$ of the site area).

The investment in Lodz has a similar total area of mixed-use development - 5381955 square feet (cca. $500000 \mathrm{~m}^{2}$ ) - as that in the French site (Fig. 2). However, its share of roadways in the development plan is much larger $-35 \%$. An analysis of the land use also shows a significant share of open public spaces, reaching almost $14 \%$ of the area. It should also be noted that these areas are slowly being delivered by the city (a tender for the New Center of Lodz square project, a.k.a. Rynek Kobro, began recently). In the vicinity of the Lodz Fabryczna train station is the historic Stanisław Moniuszko Park, constituting $6 \%$ of the entire area. The eco-friendly nature of the development is regulated in the master zoning plan, which states that $9 \%$ of the area inside the city blocks, including green roofs, will ultimately be designated for green areas (in comparison, it is only $4 \%$ in Clichy-Batignolles). A study of the urban tissue in Lodz clearly shows the ultimate domination of office use: $43 \%$. While these buildings are under construction, many public buildings are already operational in the area. It is with the public buildings that the city's modern identity is being constructed: the Lodz Fabryczna train station and the EC1 heat and power plant (Table 3). As opposed to the investment in Paris, a greater ratio of services (including retail and facilities) is planned on the Lodz site. On the other hand, the role of apartment buildings, in comparison with other functions, is relatively small. 


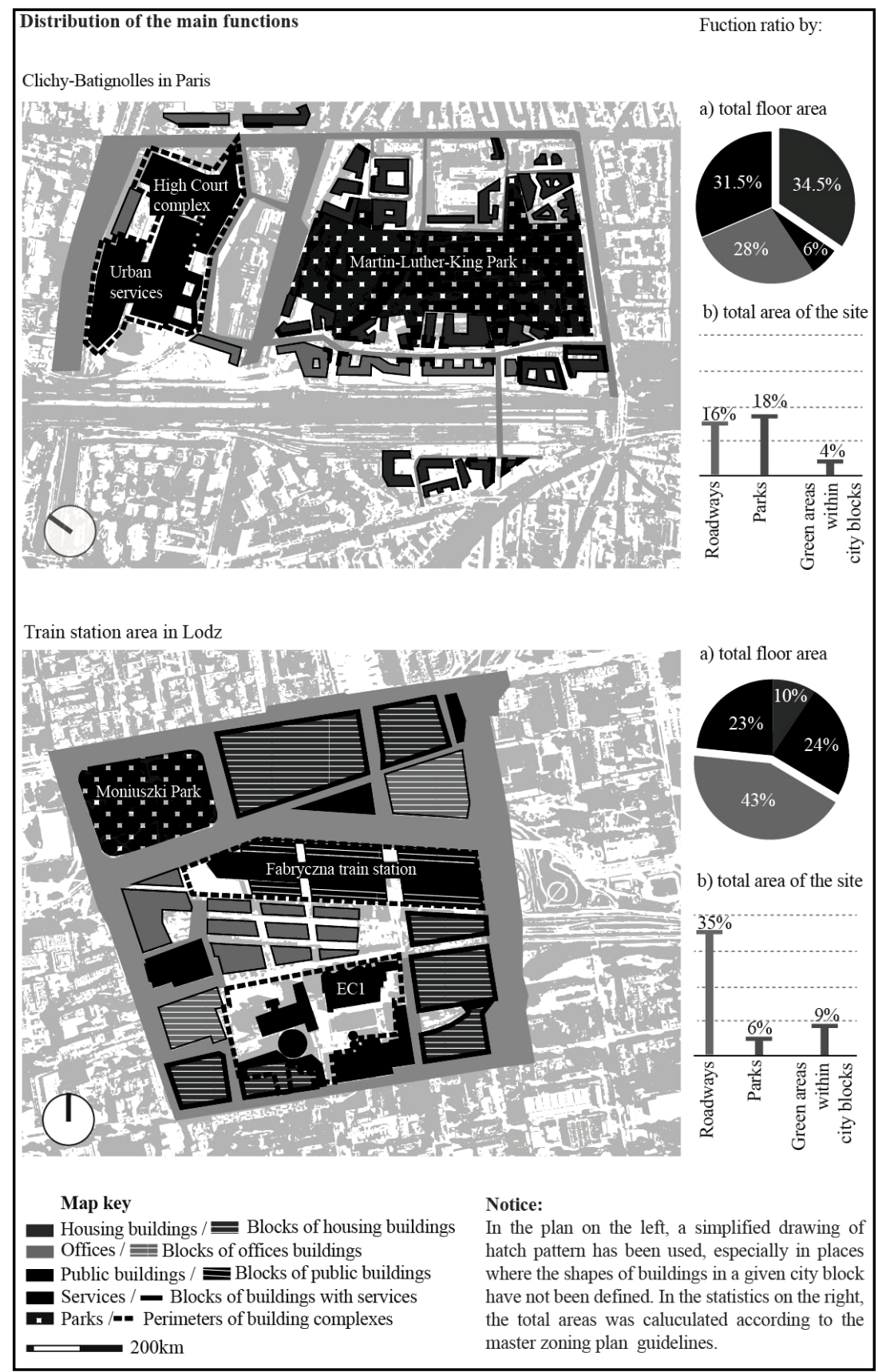

Fig. 2 - Distribution of main functions

Source: developed by the author based on Paris Batignolles Aménagement and Municipal Urban Agency data 
Testing the New Urbanism Principle of Sustainable Transport in the Contemporary Redevelopment Projects. Lessons from Clichy - Batignolles in Paris and the Station Area of Lodz

Distribution function indicator

\begin{tabular}{|c|c|c|c|}
\hline Indicator & Variable & $\begin{array}{c}\text { Clichy- } \\
\text { Batignolles }\end{array}$ & $\begin{array}{c}\text { Train station area } \\
\text { in Lodz }\end{array}$ \\
\hline \multirow{6}{*}{$\begin{array}{c}\text { Distribution } \\
\text { function }\end{array}$} & Housing use dominance & $\bullet$ & - \\
\cline { 2 - 4 } & $\begin{array}{c}\text { Office use dominance } \\
\text { agglomeration through the } \\
\text { policy for whole } \\
\text { dominant use }\end{array}$ & - & $\bullet$ \\
\cline { 2 - 4 } & $\begin{array}{c}\text { Public services which } \\
\text { mitigate environmental } \\
\text { pollution at the site }\end{array}$ & - & - \\
\cline { 2 - 4 } & Flagship investment & $\begin{array}{c}\text { Courthouse } \\
\text { (public } \\
\text { investment) }\end{array}$ & $\begin{array}{c}\text { Lodz Fabryczna } \\
\text { train station and the } \\
\text { EC1 heat and } \\
\text { power plant (public } \\
\text { investment) }\end{array}$ \\
\hline
\end{tabular}

The different interpretation of sustainable transportation

The start of the project in Lodz is closely related with the announcement of key changes in the city's and country's transportation policy. As a result, significant investments in the highway sector were supposed to be complemented by a strategic high-speed railway project. In Lodz, the change in the approach to transportation was shown through the city's zoning solutions themselves. The motto of the new district's project - Station Down, Culture Up - reflects the changes in the design tendencies and a move towards pedestrian-oriented solutions. The choice of Rob Krier, a pioneer of New Urbanism, as the main urban planner was therefore not a coincidence. The decisions to tear down the barrier that divided the city and to move the railway area underground and to modernize it were supposed to allow for a new functional and spatial quality to emerge. Ultimately, the modern multimodal station was created at the cost of tearing down the previous station completely. The railway tracks were moved underground, though only in the eastern part of the site. For now, Lodz Fabryczna still remains a terminus station. The station, now adapted to serve 200000 passengers a day, is the largest hub in that part of Europe. Unfortunately, its capacity potential remains unrealized, because the highspeed rail Poland project has not yet been introduced. The agglomeration rail network around the city is successively being extended. For example, the cross-town tunnel under the city for conventional rail is being developed. This will certainly lead to an increase in railway connections through Lodz Fabryczna, as the trains will be able to go through the station closest to the city center, without having to turn in order to move back in the direction it came from. In the area of the hub, there is also a central bus station, and it is accessible by bus and tram. There are also city bike stations in the vicinity. These investments are located in the western part and they seem somewhat weighed down by the complex road infrastructure in the eastern part. Four-lane streets now stretch from the station towards one-lane streets in the city center, which is not a strategic arterial junction in the city. The quality of the spatial solutions also varies: on the one hand, living streets known as woonerfs are being built, but, on the other hand, complicated interchanges and enormous road systems are appearing that are very difficult or even impossible for pedestrians to cross. A comparison between the former railway area and the modern road layout clearly shows that the spatial barrier has remained essentially unchanged, the only difference being it is now no longer the railway tracks that create it, but the roads. 
In the case of Clichy-Batignolles, the design of the roads appears more uniform (Table 4), with the exception of the ring road transit. Throughout the whole area, the speed limit has been reduced to $20-30 \mathrm{~km} / \mathrm{h}$ (12.5-18.5 $\mathrm{mph}$ ), which influences the quality of the sidewalks (apart from the ring road). The sense of security is strengthened by the greenery that lines the paths. In addition to creating about a dozen public bike stations, the city is now legally bound to devote $2.5 \%$ of the total area to bicycle parking. As well as the bicycle sharing system Velib, the car sharing Autolib is also available. In terms of mass transit, Clichy-Batignolles is served by the Metro line 13, RER (rapid transit rail) line $C$ and Transilien rail line $L$ (Fig. 3). The latter is connected with Gare Saint-Lazare, an important transport hub (the metro, RER, French railway company SNCF). The Pont-Cardinet station of Transilien rail line $\mathrm{L}$, which serves ClichyBatignolles, is frequented by an average of 9500 travelers per day (SNCF 2014 data). By 2019 , the connection with Saint-Lazare will have been strengthened by an extension of Line 14 of the metro, with two new stations planned to be located within the area of the site (Pont Cardinet and Porte de Clichy). Currently, line 14 carries 550000 passengers per day, and this figure should rise by $30 \%$ by 2020 , reaching 1 million in 2024, after its extension towards the north and south (these are the estimated figures of the Paris City Council and the department responsible for the issue). The investment has three strategic goals: relieving the overcrowded line 13, connecting Clichy-Batignolles with other parts of Paris, and creating a direct connection between the site and Gare de Lyon. The city is also carrying out the extension of tram line T3. Thanks to that, the Porte de Clichy station will be located in the square in front of the courthouse, where metro lines 14 and 13, the existing RER C line and the T3 tramline will all converge.

Transportation mode indicator

Table 4

\begin{tabular}{|c|c|c|c|}
\hline Indicator & Variable & Clichy-Batignolles & $\begin{array}{c}\text { Train station area } \\
\text { in Lodz }\end{array}$ \\
\hline \multirow{3}{*}{$\begin{array}{l}\text { Transportation } \\
\text { mode }\end{array}$} & $\begin{array}{l}\text { Pedestrian-oriented } \\
\text { policy }\end{array}$ & $\bullet$ & partial \\
\hline & $\begin{array}{l}\text { Transportation hub } \\
\text { within the project }\end{array}$ & - & $\bullet$ \\
\hline & $\begin{array}{c}\text { Coherence between the } \\
\text { size of the infrastructure } \\
\text { and the need of the } \\
\text { users }\end{array}$ & $\bullet$ & partial \\
\hline
\end{tabular}

The importance of the scale in transportation investments

As described above, the transportation investments connected with serving Clichy-Batignolles are aimed at creating faster and more comfortable connections between the site and the entire agglomeration. The Nouveau Grand Paris project will be a guarantee of this large-scale strategy. The extension of Line 14 is the first element of the automation of the underground, as planned in the project. The aim of Nouveau Grand Paris is to remove the inequalities in accessibility between individual city districts in Paris itself, and to towns in the suburbs, to ultimately create a sustainable environment. The program has been underway since 2013 and it includes improving the service of other means of public transport: buses, trams, rail services. Thanks to that, the Clichy-Batignolles investment will be accessible within less than 20 minutes from other major city center hubs (Châtelet-les-Halles and Gare de Lyon). On the one hand, the site is exploiting its location within the metropolitan triangle: La Défense, the central business district and Plaine Saint-Denis. On the other hand, it will be more easily accessible for the users of the suburban network of Saint-Lazare as well ${ }^{4}$.'

4) Not only will metro line 14 will be connected with the Saint-Lazare station, but also RER E will be extended towards the north. 
Testing the New Urbanism Principle of Sustainable Transport in the Contemporary Redevelopment Projects. Lessons from Clichy - Batignolles in Paris and the Station Area of Lodz

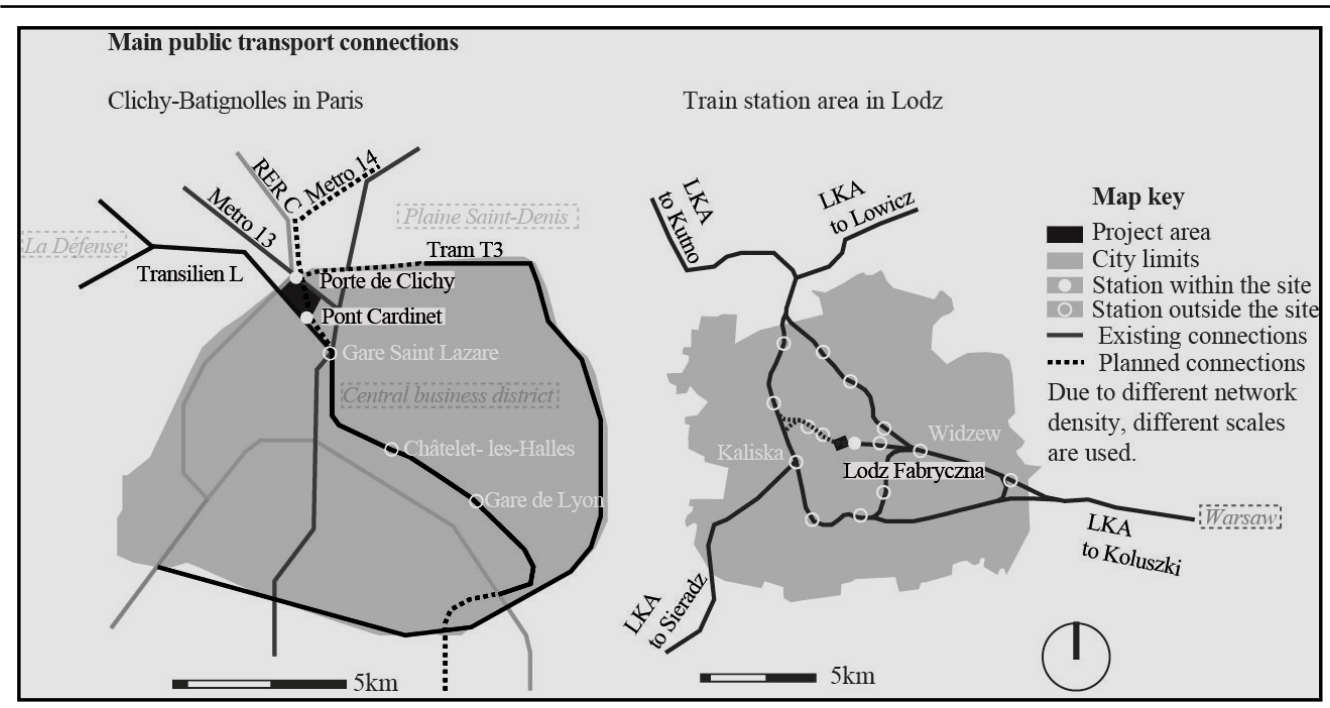

Fig. 3 - Main public transport connections

Source: developed by the author based on Paris Batignolles Aménagement and Municipal of Lodz data

The importance of the scale in transportation investments

As described above, the transportation investments connected with serving Clichy-Batignolles are aimed at creating faster and more comfortable connections between the site and the entire agglomeration. The Nouveau Grand Paris project will be a guarantee of this large-scale strategy. The extension of Line 14 is the first element of the automation of the underground, as planned in the project. The aim of Nouveau Grand Paris is to remove the inequalities in accessibility between individual city districts in Paris itself, and to towns in the suburbs, to ultimately create a sustainable environment. The program has been underway since 2013 and it includes improving the service of other means of public transport: buses, trams, rail services. Thanks to that, the Clichy-Batignolles investment will be accessible within less than 20 minutes from other major city center hubs (Châtelet-les-Halles and Gare de Lyon). On the one hand, the site is exploiting its location within the metropolitan triangle: La Défense, the central business district and Plaine Saint-Denis. On the other hand, it will be more easily accessible for the users of the suburban network of Saint-Lazare as well.

The size of the connections in Lodz cannot be compared, for obvious reasons. In any case, it is the quality of the connections between the site and the other elements in the city center, housing areas on the outskirts of the agglomeration, as well as other important urban settlements in Poland that is relevant. The project of the Lodz Fabryczna train station was accompanied by the idea of a high-speed rail line between Lodz and Warsaw, Poznan, and Wroclaw. As presented below, that project has been temporarily put on hold. In the meantime, a general renovation of the Lodz-Warszawa route has been carried out, with the aim of shortening the length of the journey down to 70 minutes (a section of about $140 \mathrm{~km}=87$ miles). The Lodz Agglomeration Railway (LKA) is, on the other hand, the basic investment on a regional scale, as it connects the neighboring towns and the individual districts in Lodz itself. The project's timeframe spans ten years and the end has been planned for 2020. Today, a significant section of it is already operational and it carries an average of 11760 passengers a day (LKA data from early 2018). As part of the LKA project, P\&R parking lots, bus stations and bike sharing stations will be located next to the train stations. The LKD stations which are 
located on the circle route should help alleviate the auto congestion, especially in the city center. Users will be able to leave their cars on the outskirts and reach the central station comfortably. A connection between the Widzew and Kaliska stations will create a shortcut in the existing network, and a cross-city tunnel is currently under construction between Fabryczna and Kaliska (Table 5).

Scale of connections indicator

Table 5

\begin{tabular}{|c|c|c|c|}
\hline Indicator & Variable & Clichy-Batignolles & $\begin{array}{c}\text { Train station area } \\
\text { in Lodz }\end{array}$ \\
\hline \multirow{3}{*}{$\begin{array}{c}\text { Scale of } \\
\text { connections }\end{array}$} & $\begin{array}{c}\text { Direct connection to the city } \\
\text { centre }\end{array}$ & in progress & in progress \\
\cline { 2 - 4 } & $\begin{array}{c}\text { Direct connection to the } \\
\text { agglomeration } \\
\text { transportation network }\end{array}$ & - & \\
\cline { 2 - 4 } & $\begin{array}{c}\text { Direct connection to the } \\
\text { national transportation net }\end{array}$ & - & \\
\hline
\end{tabular}

Car park ratio as a tool of sustainable urban policy

The general policy in Paris is to drastically limit the number of parking spaces. After an update in the local master plan (PLU), there is no longer a ratio of parking places that needs to be imposed, except for office use (since 2016). There are no constraints as to the number of parking places in public spaces (be it public squares or roadside parking places). However, an analysis of the Clichy-Batignolles structure clearly shows that parking places have been created mainly for residents rather than for employees, who are discouraged from commuting by car to that neighborhood. Regulations from the previous PLU and the operational development plan $(\mathrm{ZAC})$ were used to control the issue of parking.

Moreover, Paris Batignolles Aménagement, a local public company (SPL) responsible for conducting the development operation, after consulting a specialized design office, additionally registered the following ratio in the tender documentation, and later in the contract of sale (Cahiers des Charges de Cession de Terrain des actes de vente):

- $\quad$ offices : 0.353 car places for 1,075 square feet $\left(100 \mathrm{~m}^{2}\right)$ of floor area;

- $\quad$ commerce and services: 0.28 car places for 1075 square feet $\left(100 \mathrm{~m}^{2}\right)$ of floor area;

- $\quad$ housing: one car place per 1075 square feet $\left(100 \mathrm{~m}^{2}\right)$ of housing area.

In Clichy-Batignolles, a residential car park for 600 vehicles was created. It is operated by a semi-public company (Saemes). On the whole site, however, there will only be two car parks for non-residents, able to fit 200 and 250 spaces.

These numbers are far smaller than those on the Lodz site, where the Fabryczna station car park can hold 960 vehicles and it is accessible free of charge for all users. Next to it, another construction is planned with over 300 underground parking spaces. This is an element of a new square and underground road development that has just been started. However, the new neighboring office investments are failing to make full use of the possibilities that the master zoning plan presents. The plan regulates the parking place ratio (Table 6) as follows:

* housing: between 0.5 and 1 place per apartment;

* commerce: between 3 and 8 freely accessible places per 10750 square feet $\left(1000 \mathrm{~m}^{2}\right)$ of floor area; 
Testing the New Urbanism Principle of Sustainable Transport in the Contemporary Redevelopment Projects. Lessons from Clichy - Batignolles in Paris and the Station Area of Lodz

* $\quad$ public administration and offices: at least 3 places per 10750 square feet $\left(1000 \mathrm{~m}^{2}\right)$ of floor area.

Table 6

Car parking policy indicator

\begin{tabular}{|c|c|c|c|}
\hline Indicator & Variable & $\begin{array}{c}\text { Clichy- } \\
\text { Batignolles }\end{array}$ & $\begin{array}{c}\text { Train station area } \\
\text { in Lodz }\end{array}$ \\
\hline \multirow{3}{*}{$\begin{array}{l}\text { Car parking } \\
\text { policy }\end{array}$} & $\begin{array}{l}\text { Parking spaces quantity } \\
\text { limitation policy }\end{array}$ & $\bullet$ & 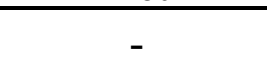 \\
\hline & $\begin{array}{l}\text { Parking created at the site } \\
\text { are mostly dedicated to } \\
\text { residents }\end{array}$ & $\bullet$ & - \\
\hline & $\begin{array}{l}\text { Parking created at the site } \\
\text { are mostly dedicated to } \\
\text { external users }\end{array}$ & - & • \\
\hline
\end{tabular}

\section{Discussion}

The results presented above yield new insights into the existing research in the field of sustainable transportation with aspects related to New Urbanism. An attempt was made to define efficient spatial solutions that would make it possible to (re)create landscapes that are not dominated by cars. Elements that improve mobility and accessibility, as defined by New Urbanism, were therefore the key.

In projects that rely on sustainable transportation, the location itself is extremely important. In both cases under analysis, the location along a degraded, post-railway line unlocked the new potential of the place, drawing on the existing modernized infrastructure. This approach is not only coherent with the idea of sustainable transportation, but also with urban regeneration. While the general positive accounts of New Urbanism principles, including the principle of sustainable transportation, are slowly becoming convincing (Fainstein 2000, Dierwechter and Coffey 2017), its value in redevelopment projects intra muros remains largely unexplored. Taking action within the central area of the urbanized environment is the contemporary adaptation of New Urbanism guidelines.

Given the value of the area, the timing of the investment is crucial. Since urban projects are generally thought of as long-term plans, it is rational that the timespan of the developments in Lodz and in Paris should stretch over a 20-25-year-long period. During this time, the investments are influenced by changes in political and economic circumstances. The basic ideas and decisions, however, should not be altered, especially those connected with sustainable transportation. Unfortunately, due to the prolongation of the Polish TGV program, this kind of change did somehow take place in Lodz. The development of high-speed rail in Poland was put on hold, even though it was supposed to pave the way for developments throughout the station area.

The implementation of the ideas behind sustainable transportation should include, on a large scale - interconnecting metropolises, cities, and districts with each other, and on a small scale - creating a network of connections within city blocks for pedestrians, cyclists, cars, and various means of public transport. The research complements the existing findings about the influence of the urban environment on the travel behavior (Joh et al. 2009, Marshall 2015) with aspects related to different scales of urban policy and mass transit. In the metropolis, these guidelines are achieved at the already discussed Nouveau Grand Paris project, and within the 
site - by the local master plan (PLU) and the operational development plan (ZAC).

In Lodz, although the idea of sustainable transportation is implemented in the agglomeration railway project, the guidelines included in the master zoning plan (MPZP) do not rise to the challenge. Attempts have been made to render the area around the station more accessible to cyclists, but the attempts were ultimately much smaller than the investments concerning car transportation. This is best illustrated by the domination of the roadway in the train station area in Lodz, which is twice as large as that in Clichy-Batignolles.

Parking policy is also relevant when assessing the level of sustainable transportation. In Paris, while the number of parking places for non-residents continues to be limited, a net of public transport is developing. In Lodz, on the other hand, significant parking areas are still being created in the new station developments, which are paid for by the country and they are free to all users. Those who have a choice will opt to reach the NCL by car rather than by the developing public transport. In Lodz, public network connections between the site and other elements of the city center, and between the site and the housing areas on the outskirts of the agglomeration, need to be facilitated.

The results presented by the article complement the existing research also in the relations between density, land-use diversity, and pedestrian-oriented designs on non-motorized travel (Cervero and Kockelman 1997, Talen 2013, Wohl 2017). So far, it has been assumed that the relations between these elements (Table 7) are statistically significant, but of marginal influence. Assuming sustainable transportation as one of the tenets of New Urbanism, as our study has done, the relation becomes clear and significant.

Table 7

Review of indicators

\begin{tabular}{|l|l|}
\hline \multicolumn{1}{|c|}{ Indicator } & \multicolumn{1}{|c|}{ Lesson } \\
\hline Location & $\begin{array}{l}\text { The strategic position of redevelopment projects located on rail lines } \\
\text { allows to rebuild the continuity of urban fabric as well as, to create a new } \\
\text { centrality for the area in question, with attractive cultural activities and } \\
\text { services. }\end{array}$ \\
\hline Timeframe & $\begin{array}{l}\text { As the urban project timeframe are long, high flexibility and the ability to } \\
\text { adopt investments to changing conditions is required. However, the } \\
\text { realization of the investment's key infrastructure elements should be } \\
\text { maintained all along. }\end{array}$ \\
\hline $\begin{array}{l}\text { Functional } \\
\text { plan }\end{array}$ & $\begin{array}{l}\text { The functional plan can be an important support for the sustainability of } \\
\text { the project because on it ensures the quality of the urban tissue through } \\
\text { the public high-standard investments, thereby defining a new image for } \\
\text { the area. Furthermore, the distribution of uses can serve an pertinent } \\
\text { response for the strategic needs of the entire agglomeration. }\end{array}$ \\
\hline $\begin{array}{l}\text { Transporta- } \\
\text { tion mode }\end{array}$ & $\begin{array}{l}\text { The quality of the adopted spatial solutions should be coherent with } \\
\text { pedestrian-friendly strategies. }\end{array}$ \\
\hline $\begin{array}{l}\text { Scale } \\
\text { of } \\
\text { connections }\end{array}$ & $\begin{array}{l}\text { The implementation of sustainable transportation should include quick } \\
\text { and comfortable connection by various means of public transportation } \\
\text { within different urban scales: metropolises, cities, districts and the city } \\
\text { center. }\end{array}$ \\
\hline $\begin{array}{l}\text { Car parking } \\
\text { policy }\end{array}$ & $\begin{array}{l}\text { Limitation of the car park ratio for non-residents in inner city } \\
\text { redevelopment projects, in conjunction with the development of the public } \\
\text { transportation network, can become an effective tool of sustainable urban } \\
\text { policy. }\end{array}$ \\
\hline
\end{tabular}


Testing the New Urbanism Principle of Sustainable Transport in the Contemporary Redevelopment Projects. Lessons from Clichy - Batignolles in Paris and the Station Area of Lodz

\section{Conclusions}

The conclusions ought to be regarded in the context of the functional plan. The New Urbanism definition of compact development is important. Krier (2009) noted that public spaces should take up between $25 \%$ and $35 \%$ of the total area of the site. In Lodz, however, the roadways alone take up $35 \%$, and to that another $14 \%$ of other public spaces that are not roadways are to be added. This confirms the excess of public spaces in the Lodz site, while simultaneously highlighting the more correct proportions of public spaces in Clichy-Batignolles. In addition, in both cases the density of the build-up is worth mentioning. The indicators are similar - the one in Lodz is even slightly higher than the one in Paris. If the average floor area ratios in the analyzed sites (which amount to 1) are compared with the average floor area ratios in the historical districts (which amount to 2), both projects appear to be pedestrian-friendly. However, these indicators have been calculated for the entire area of the development, which includes green park areas. A closer look at the intensity indicator for the individual floor area ratio makes it clear that in Lodz it wavers between 2 and over 6 (by comparison, it reaches over 6 in the city center of London). This points to a built-up structure that is too dense, especially when we compare it to the target capacity of public transport in the area, e.g. the Lodz agglomeration rail.

Sustainable transportation is also affected by the functional ratio. The domination of one function over another is problematic. Solutions that would allow various uses to exist in one area, so as to minimize the daily commute of residents, are necessary. From this perspective, the target share of offices planned in the analyzed area in Lodz - over $43 \%$ of all functions, and the relatively large $24 \%$ service spaces (in addition to $23 \%$ of public buildings) - is alarming. When we compare the user flow, which is much lower than in Paris, it is perhaps surprising to assume that Lodz will be overflowing with users and it will be easily accessible.

Finally, the issue of managing the project needs to be addressed in such a way that the guidelines of sustainable transportation can be implemented swiftly and smoothly. The importance of governance based on cooperation between the public and private spheres in green innovations is well-known in the literature (Rossiter and Smith 2018). The presented study developed this model by adding conclusions connected with sustainable transportation projects. As described above, Paris Batignolles Aménagement could serve as an example. The unit responsible for the analysis and guidelines, including the parking policy in the site. The Paris Batignolles Aménagement also coordinates the activities with strategic public actors, including branches responsible for regional transport and private investors. This makes it possible to exercise some control over the evolution of the plots in the district, in the context of sustainable development specifications.

In that respect, a deposit of $4 \%$ of the sale price of the plot was introduced. After all, the ultimate goal is sustainable development for the entire area that will take full advantage of the proposed modality transport and its capacity. It is a solution that is worth careful consideration when thinking of other investments of this type, including the station area in Lodz.

Thanks to that, the priority mode of transport and other elements that determine user comfort will remain under better control. As it has already been shown in this research paper, the coherence of many various actions is important in the pursuit of sustainable development (Table 8). This, in turn, is ensured by treating it as one of the -- of New Urbanism. The proposed approach will guarantee a high quality of contemporary urban redevelopment projects, especially if they are combined with other guidelines of pedestrian-oriented urban patterns. 


\section{Further guidance}

Table 8

\begin{tabular}{|l|l|}
\hline \multicolumn{1}{|c|}{ Threats } & \multicolumn{1}{c|}{ Recommendation } \\
\hline $\begin{array}{l}\text { Too much space dedicated to } \\
\text { roadways }\end{array}$ & $\begin{array}{l}\text { Change the proportions of land dedicated to cars in } \\
\text { favor of land dedicated to pedestrians (Lodz). }\end{array}$ \\
\hline Too high intensity indicator & $\begin{array}{l}\text { Reduce the density of un-built zones (Lodz) and } \\
\text { invest in high quality public spaces (Lodz and Clichy- } \\
\text { Batignolles). }\end{array}$ \\
\hline $\begin{array}{l}\text { Too much area reserved for open } \\
\text { public space }\end{array}$ & $\begin{array}{l}\text { Limit inappropriately designed open spaces } \\
\text { especially spaces dedicated to cars (Lodz). }\end{array}$ \\
\hline $\begin{array}{l}\text { Insufficient proportion of } \\
\text { housing use. }\end{array}$ & $\begin{array}{l}\text { Locate more housing investments close to the } \\
\text { neighborhood (Lodz). }\end{array}$ \\
\hline $\begin{array}{l}\text { Too much weight given to } \\
\text { services functions }\end{array}$ & $\begin{array}{l}\text { Provide strategic offer for potential tenants (Lodz). } \\
\text { Advertise the area as a place well addressed to } \\
\text { potential investments and future users (Lodz and } \\
\text { Clichy-Batignolles). }\end{array}$ \\
\hline $\begin{array}{l}\text { Weak cooperation between } \\
\text { public and private stakeholders }\end{array}$ & $\begin{array}{l}\text { Definition of private and public roles in the urban } \\
\text { governance of the site (Lodz). }\end{array}$ \\
\hline
\end{tabular}

\section{References}

BOARNET M. G., CRANE R. (2001), Travel by design: The influence of urban form on travel, Oxford University Press, Oxford.

CALTHORPE P. (1993), The Next American metropolis: Ecology, community, and the American Dream, Princeton Architectural Press, New York.

CALTHORPE P. (2000), New Urbanism and the Apologists for Sprawl, Places 13 (2), 67 $-69$.

CERVERO R. (1996), Mixed land-uses and commuting: Evidence from the American Housing Survey, Transportation Research Part A: Policy and Practice 30 (5), 361-377.

CERVERO R., KOCKELMAN K. (1997), Travel demand and the 3Ds: Density, diversity, and design, Transportation Research Part D: Transport and Environment 2 (3), 199-219.

CERVERO R., RADISCH C. (1996), Travel choices in pedestrian versus automobile oriented neighborhoods, Transport Policy 3 (3), 127-141.

CERVERO R., SULLIVAN C. (2011), Green TODs: marrying transit-oriented development and green urbanism, International Journal of Sustainable Development \& World Ecology 18 (3), 210-218.

CONGRESS FOR THE NEW URBANISM (2000), Charter of the New Urbanism, Retrieved from: https://www.cnu.org.

COUDROY DE LILLE L. (2016), Introduction - Entre Est et Ouest : une européanisation urbaine, Revue Géographique de l'Est 56 (3-4), 1-15.

CRANE R., CREPEAU R. (1998), Does neighborhood design influence travel? A behavioral analysis of travel diary and GIS data, Transportation Research Part D: Transport and Environment 3 (4), 225-238.

DIERWECHTER Y., COFFEY B. (2017), The travels, triumphs and travails of new urbanism: representational geographies in US newspapers, 1990-2012, Journal of Urbanism: International Research on Placemaking and Urban Sustainability 10 (4), 385-400.

DORSEY B., MULDER A. (2013), Planning, place-making and building consensus for transit-oriented development: Ogden, Utah case study, Journal of Transport Geography 32, 6576.

ELLIS C. (2002), The New Urbanism: Critiques and Rebuttals, Journal of Urban Design 
Testing the New Urbanism Principle of Sustainable Transport in the Contemporary Redevelopment Projects. Lessons from Clichy - Batignolles in Paris and the Station Area of Lodz

7 (3), 261-291

EUROPEAN COMMISSION (2011), Roadmap to a single European transport area Towards a competitive and resource efficient transport system, White Paper COM (2011) 144 final, Retrieved from: https://ec.europa.eu.

EUROPEAN COMMUNITIES COMMISSION (1993), The future development of the common transport policy. A global approach to the construction of a Community framework for sustainable mobility, Bulletin of the European Communities S. 3/93, 1-72.

FAINSTEIN S. S. (2000), New Directions in Planning Theory, Urban Affairs Review 35 (4), 451-478

FARR D. (2008), Sustainable Urbanism: Urban Design with Nature, Wiley, Hoboken.

FAURE A. M. (1994), Some Methodological Problems in Comparative Politics, Journal of Theoretical Politics 6 (3), 307-322.

FRANK L. D., PIVO G. (1994), Impacts of mixed use and density on utilization of three modes of travel: single-occupant vehicle, transit, and walking, Transportation Research Record 1466, 44-52.

GREENWALD M. J., BOARNET M. G. (2002), Built environment as determinant of walking behavior: Analyzing nonwork pedestrian travel in Portland, Oregon, Transportation Research Record 1780 (1), 33-41.

INTERNATIONAL ENERGY AGENCY (2009), Transport, energy and $\mathrm{CO}_{2}$ : Moving towards sustainability, International Energy Agency, Paris.

JOH K., BOARNET M. G., NGUYEN M. T., FULTON W., SIEMBAB W., WEAVER S. (2008), Accessibility, travel behavior, and new urbanism: Case study of mixed-use centers and auto-oriented corridors in the South Bay Region of Los Angeles, California, Transportation Research Record 2082 (1), 81-89.

KRIER L. (2009), The Architecture of Community, Island Press, Washington, D.C.

KUNSTLER J. H. (1993), The Geography of Nowhere: The Rise and Decline of America's Man-Made Landscape, Simon \& Schuster, New York.

LANGDON P. (2017), Within Walking Distance: Creating Livable Communities for All, Island Press, Washington, D.C.

LIN J. J., GAU C. C. (2006), A TOD planning model to review the regulation of allowable development densities around subway stations, Land Use Policy 23 (3), 353-360.

MA X., CHEN X., LI X., DING C., WANG Y. (2018), Sustainable station-level planning: An integrated transport and land use design model for transit-oriented development, Journal of Cleaner Production 170, 1052-1063.

MARSHALL W. E. (2015), Understanding the impacts of integrating New Urbanist neighborhood and street design ideals with conventional traffic engineering standards: the case of Stapleton, Journal of Urbanism: International Research on Placemaking and Urban Sustainability 8 (2), 148-172.

MOUDON A. V., HESS P. M., SNYDER M. C., STANILOV K. (1997), Effects of site design on pedestrian travel in mixed-use, medium-density environments, Transportation Research Record 1578 (1), 48-55.

NADIN V. (2012), International Comparative Planning Methodology: Introduction to the Theme Issue, Planning Practice \& Research 27 (1), 1-5.

PAPA E., BERTOLINI L. (2015), Accessibility and Transit-Oriented Development in European metropolitan areas, Journal of Transport Geography 47, 70-83.

QVISTRÖM M., BENGTSSON J. (2015), What Kind of Transit-Oriented Development?

Using Planning History to Differentiate a Model for Sustainable Development, European Planning Studies 23 (12), 2516-2534.

RODRÍGUEZ D. A., KHATTAK A. J., EVENSON K. R. (2007), Can New Urbanism Encourage Physical Activity? Comparing a New Urbanist Neighborhood with Conventional Suburbs, Journal of the American Planning Association 72 (1), 43-54.

ROSSITER W., SMITH D. J. (2018), Green Innovation and the Development of Sustainable Communities: The case of Blueprint Regeneration's Trent Basin Development, The International Journal of Entrepreneurship and Innovation 19 (1), 21-32. 
SAELENS B. E., SALLIS J. F., FRANK L. D. (2003), Environmental correlates of Walking and Cycling: Findings from the Transportation, Urban Design, and Planning Literatures, Annals of Behavioral Medicine 25 (2), 80-91.

SCHUYLER D. (1997), Review: The new urbanism and the modern metropolis, Urban History 24 (3), 344-358.

SKALSKI K. (2009), Rewitalizacja we Francji - zarządzanie przekształceniami obszarów kryzysowych $w$ miastach (Urban regeration in France, management of the transformation of crisis areas in cities), Rewitalizacja Miast Polskich, Cracow.

SPECK J. (2012), Walkable City: How Downtown Can Save America, One Step at a Time, Farrar, Straus and Giroux, New York.

TALEN E. (2008), Design for Diversity: exploring socially mixed neighbourhoods, Architectural Press, Oxford.

TALEN E. (ed.) (2013), Charter of New Urbanism (2nd ed.), McGraw-Hill, New York.

TELLIS W. M. (1997), Introduction to case study, The Qualitative Report 3 (2), 1-14.

RESOLUTION NO. III/40/14 OF THE CITY COUNCIL IN LODZ (2014), Uchwała Nr. III/40/14 Rady Miejskiej w Łodzi w sprawie uchwalenia miejscowego planu zagospodarowania przestrzennego dla części obszaru miasta Łodzi położonej w rejonie ulic: Prezydenta Gabriela Narutowicza, dr. Stefana Kopcińskiego i Juliana Tuwima na wschód od planowanego przedłużenia ulicy Uniwersyteckiej (Resolution No. III/40/14 of the City Council in Lodz on the adoption of a local zoning plan for a part of the city of Lodz located in the vicinity of streets: Prezydenta Gabriela Narutowicza, dr. Stefan Kopciński and Julian Tuwim east of the planned extension of Uniwersytecka street), Lodz City Council, Lodz.

RESOLUTION NO. III/41/14 OF THE CITY COUNCIL IN LODZ (2014), Uchwała Nr. III/41/14 Rady Miejskiej w Łodzi w sprawie uchwalenia miejscowego planu zagospodarowania przestrzennego dla części obszaru miasta Łodzi położonej w rejonie ulic: Prezydenta Gabriela Narutowicza, Williama Lindleya, Wodnej, Julian a Tuwima i Henryka Sienkiewicza Lodz (Resolution No. III/41/14 of the City Council in Lodz on the adoption of a local zoning plan for a part of the city of Lodz located in the vicinity of streets: Prezydenta Gabriela Narutowicza, William Lindleya, Wodna, Julian a Tuwima and Henryk Sienkiewicz Lodz), Lodz City Council, Lodz.

WBCSD (2004), Mobility 2030: Meeting the challenges to sustainability, World Business Council for Sustainable Development, Retrieved from: https://www.oecd.org.

WOHL S. (2017), From form to process: Re-conceptualizing Lynch in light of complexity theory, Urban Design International 22 (4), 303-317.

WORLD BANK (1996), Sustainable transport: priorities for policy reform, Development in practice, The World Bank, Washington, D.C.

Initial submission: 12.09 .2018

Revised submission: 22.12.2018

Final acceptance: 07.05.2019

Correspondence: Faculty of Civil Engineering, Architecture and Environmental Engineering, Institute of Architecture and Urban Planning, Lodz University of Technology, Stefana Żeromskiego 116, 90-924 Łódź, Poland.

Email: monika.cysek@p.lodz.pl 